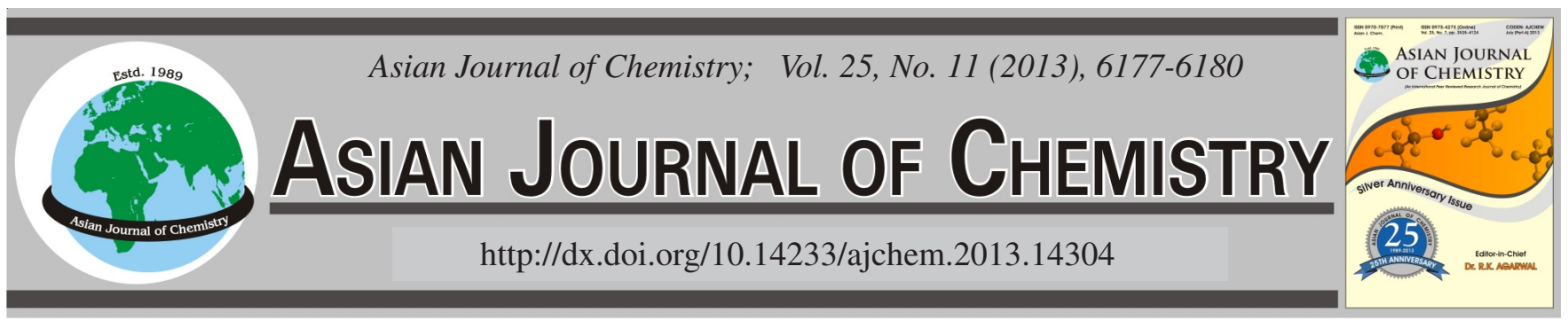

\title{
Seasonal Changes in Mineral and Trace Elements of Çanak Cheese
}

\author{
S.S. KIRDAR ${ }^{1, *}$, E. OCAK ${ }^{2}$, S. KösE ${ }^{1}$ and E. ÖZER ${ }^{3}$
}

\begin{abstract}
${ }^{1}$ Department of Food Processing, Vocational Higher Education School, Mehmet Akif Ersoy University, Burdur, Turkey ${ }^{2}$ Department of Food Engineering, Faculty of Engineering and Architecture, Yuzuncu Yil University, 65080 Van, Turkey ${ }^{3}$ Department of Nutrition and Dietetics, Faculty of Health Sciences, Near East University, Nicosia, Cyprus
\end{abstract}

*Corresponding author: Fax: +90 248 2345604; Tel/Fax: +90 248 2134575; E-mail: skirdar@mehmetakif.edu.tr

Seasonal changes of the ash content and mineral concentrations in Çanak cheese were studied. Mineral, trace and heavy metals including calcium, potassium, magnesium, copper, manganese, iron and zinc were analyzed using atomic absorption spectrometry. At the end of the study, the ash content averaged $3.85 \pm 0.26 \%$ in the winter samples and $3.00 \pm 0.14 \%$ in the summer ones. The mean concentration of $63,92,296,74$ and $1571,60 \mathrm{mg} / \mathrm{kg}$ (in winter) and 56,69, 225,61 and $1221.46 \mathrm{mg} / \mathrm{kg}$ (in summer) were measured for $\mathrm{Mg}, \mathrm{K}$ and $\mathrm{Ca}$, I respectively. The concentration of the tested metals was in the range $\mathrm{Zn}>\mathrm{Fe}>\mathrm{Cu}>\mathrm{Mn}$ over two seasons. Differences in mineral contents in the cheese making season was statistically significant $(p<0.01)$ significant seasonal variation was found for $\mathrm{Ca}, \mathrm{K}, \mathrm{Mn}$ and $\mathrm{Fe}$ $(p<0.01)$.

Key Words: Trace metals, Minerals, Atomic absorption spectrometry, Anatolia region, Cheese, Çanak cheese.

\section{INTRODUCTION}

Dairy foods are good sources of protein, calcium, riboflavin, phosphorus, potassium, vitamin A and vitamin D. The dairy group is one of the biggest contributors to calcium intake, which is extremely important for bone health ${ }^{1}$. The comsumption of cheese is of great nutritional interest, due in particular to its composition of micronutrients and especially minerals ${ }^{2,3}$. The trace metal content of cheese is variable because of factors such as differences between the types, the geographical area, the characteristics of the manufacturing procedures and possible contamination from the equipment during the process, packaging and storage. It is necessary to check the manufacturing process at each step in order to determine the source and levels of contamination and to ensure the desired product quality ${ }^{4}$.

The composition of cheese, in terms of minerals, is rather variable and depends on such factors as: (i) the initial composition of the milk, which in turn depends on the breed, the stage of lactation, the physiological condition of the animal composition of the feed and environmental ${ }^{5}$; (ii) cheese making procedures ${ }^{6}$, which are different for diferent cheese types; and (iii) ripening condition, which includes not only the temperature and the relative humidity prevailing in the maturation room, but also the protocols of the surface salting and washing ${ }^{5-7}$.
The heavy metal present in the cheese is fundamentally related to the manufacturing practices and possible contamination from the equipment during the process ${ }^{8-10}$.

The levels of trace elements, important for nutritional and/ or toxicological properties in some traditional and innovative dairy products, contribute to the characterization of the quality and adequacy of the Turkish diet ${ }^{11}$.

The most famous variety of cheese in Turkey is Çanak cheese. This type of cheese is manufactured in small-scale dairies and also homemade, using raw milk without a starter, using traditional techniques ${ }^{12}$. This study attempts to contribute to the characterization of the mineral and trace element profile of Çanak cheese during the cheese making season.

\section{EXPERIMENTAL}

In total, 40 ripened Çanak cheese samples ( $c a .250 \mathrm{~g}$ each) were purchased from randomly selected producers in the Yozgat province, in the Anatolia Region, over two seasons (summer and winter).

The Çanak cheese samples were transported to the laboratory and kept at $c a .4{ }^{\circ} \mathrm{C}$ until they were analyzed. The ash content of the cheese was quantified by dry ashing the samples in a muffle furnace at $550{ }^{\circ} \mathrm{C}$ for $24 \mathrm{~h}$. Before the samples were placed in the muffle furnace, they were dried in an oven at $105^{\circ} \mathrm{C}^{13}$. 
Mineral analysis: Concentrations of $\mathrm{Ca}, \mathrm{Mg}, \mathrm{K}, \mathrm{Cu}, \mathrm{Zn}$, $\mathrm{Fe}$ and $\mathrm{Mn}$ were quantified with an atomic absorption spectrophotometer (ATI Unicam-929-England). For the mineral analysis, all the reagents were of an analytical grade. All the reagents and samples were prepared in double distilled water. Standard solutions were freshly prepared from a 1000 ppm stock solution and a linear calibration curve was used. Wavelengths used for the tested elements were K: 766.5, Ca: 422.7, Mg: 285.2, Zn: 213.9, Fe: 248.3, Cu: 324.8 and Mn: 279.5 $\mathrm{nm}$, respectively. All the analyses were performed in duplicate $^{13}$.

Statistical analysis: All of the statistical calculations were performed using SPSS Statistical Software and the obtained values were presented as the mean \pm SE. The evaluation of significance was performed by an analysis of variance, followed by the Duncan test. The significance level of $p<0.01$ was used for determining the statistical differences ${ }^{14}$.

\section{RESULTS AND DISCUSSION}

The ash content was in the range of 2.16-5.98\%, averaging $3.85 \pm 0.26 \%$ in the winter samples and $2.13-4.14 \%$, averaging $3.00 \pm 0.14 \%$ in the summer samples. These results could have originated from the milk composition and the different production techniques ${ }^{15}$.

The content of all the detected major elements in the Çanak cheese derived in winter was higher than in samples from the summer, especially concerning calcium, potassium and magnesium (Fig. 1, Table-1) which can be explained by animal feeds and breeding distinctions between the seasons.

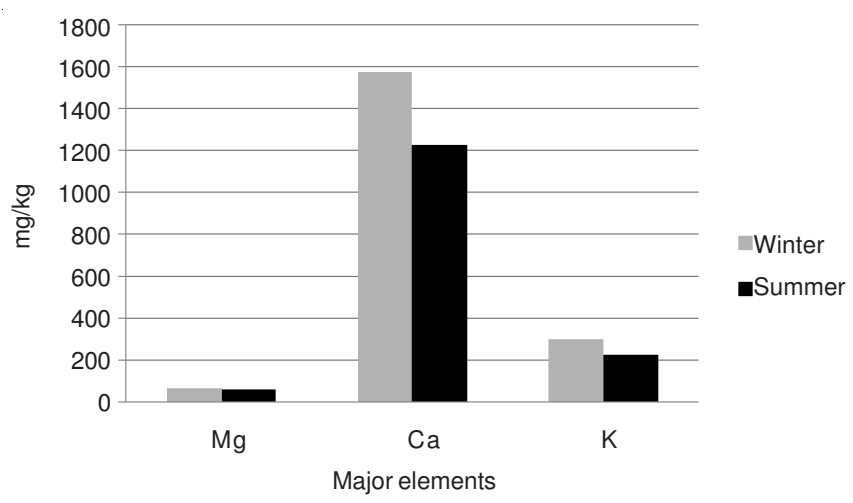

Fig. 1. Major elements of Çanak cheese

Calcium: Calcium plays a major regulatory role in numerous biochemical and chemical physiological processes and it must be ingested with the daily diet. Milk and milk products, especially cheese, play an important role in the calcium intake in the body ${ }^{16}$.

The mean calcium concentration of the samples varied from $250,01-3487,96 \mathrm{mg} / \mathrm{kg}$. The level of calcium in the Çanak cheese was higher than Tulum, Kashar and White cheese ${ }^{17}$. Çanak cheese is recommended for an adequate calcium intake in a daily diet.

Potassium: The maximum potassium content was found to be $296,74 \mathrm{mg} / \mathrm{kg}$ (in winter) and $225,62 \mathrm{mg} / \mathrm{kg}$ (in summer). The potassium content of Çanak cheese was higher than the Tulum and Kashar cheese ${ }^{17}$, but lower than the Akçakatik
TABLE-1

MAJOR ELEMENTS OF ÇANAK CHEESE

\begin{tabular}{cccc}
\hline & $\mathrm{M} \pm \mathrm{SE}$ & Minimum & Maximum \\
\hline \multicolumn{3}{c}{ Winter } \\
\hline $\mathrm{Ca}$ & $1571.60 \pm 198.25$ & 250.01 & 3487.96 \\
$\mathrm{Mg}$ & $63.92 \pm 11.37$ & 0.01 & 171.40 \\
$\mathrm{~K}$ & $296.74 \pm 20.32$ & 152.04 & 474.95 \\
$\mathrm{Cu}$ & $1.32 \pm 0.16$ & 0.17 & 2.37 \\
$\mathrm{Fe}$ & $4.44 \pm 0.44$ & 1.51 & 10.44 \\
$\mathrm{Zn}$ & $17.52 \pm 2.39$ & 2.44 & 43.87 \\
$\mathrm{Mn}$ & $0.23 \pm 0.02$ & 0.03 & 0.45 \\
\hline \multicolumn{3}{c}{ Summer } \\
$\mathrm{Ca}$ & $1221.46 \pm 139.57$ & 341.83 & 2464.34 \\
$\mathrm{Mg}$ & $56.68 \pm 3.23$ & 34.06 & 77.06 \\
$\mathrm{~K}$ & $225.62 \pm 21.70$ & 59.25 & 364.50 \\
$\mathrm{Cu}$ & $1.55 \pm 0.17$ & 0.54 & 3.43 \\
$\mathrm{Fe}$ & $7.15 \pm 0.79$ & 2.22 & 13.46 \\
$\mathrm{Zn}$ & $13.41 \pm 1.28$ & 4.88 & 23.65 \\
$\mathrm{Mn}$ & $0.39 \pm 0.04$ & 0.12 & 0.74 \\
\hline
\end{tabular}

cheese $^{15}$. There were statistical differences regarding the $\mathrm{Ca}$ content during the cheesemaking season $(p<0.01)$.

Magnesium: Magnesium is important for nucleic acid and protein metabolism, communication between neurons and muscles and especially the muscle system and it has also been reported that magnesium, together with calcium. Milk and milk products are not the principal sources for magnesium intake, but they do play a partial role in $\mathrm{it}^{1,18}$.

The magnesium content ranged from 10,01-171,40 mg/ $\mathrm{kg}$. The level of magnesium in the Çanak cheese is higher than in winter. With regard to $\mathrm{Mg}$ (in milk for $70 \%$ in soluble form and for $30 \%$ in colloidal form) Çanak cheese has quantities lower than other cheeses ${ }^{9,19}$. The $\mathrm{Ca}$ and $\mathrm{Mg}$ concentration were affected more by the season than were the other groups of minerals ${ }^{20}$.

The mineral content of the Çanak cheese, determined by the characteristics of the relationship between the correlation coefficients, was calculated to determine the significance. The statistical evolution results are given in Tables 2 and 3. The correlation coefficient between the potassium and magnesium, calcium and magnesium and calcium and potassium was $\mathrm{r}=0.660,0.547$ and $0.926(p<0.01)$, respectively.

The high correlation coefficient observed between the calcium and potassium $(\mathrm{r}=0.926, p<0.01)$ indicated which cheesemaking season. These results could be partially accounted for by the variations in the milk compositions arising from the qualitatively and quantitatively different metabolic rates, as well as the different characteristics of the feeding available ${ }^{7}$.

The content of the minor elements in the Çanak cheese derived in the summer was higher than in the samples in the winter, except zinc (Fig. 2).

Iron: The iron values in this study were found to be 4.44 $\mu \mathrm{g} / 100 \mathrm{~g}$ in winter and $7.15 \mu \mathrm{g} / 100 \mathrm{~g}$ in summer, respectively. The mean value for $\mathrm{Fe}$ in this research was similar to that found in Ordu Çerkez cheese and Kashar Cheese ${ }^{1,8}$, but higher than that of Italian Ricotta cheese ${ }^{21}$ and White cheese ${ }^{11}$. There were statistical differences regarding the Fe content during the cheesemaking season $(p<0.01)$.

Copper: Copper is known to be important and toxic for many biological systems. It may enter food materials from 
TABLE-2

CORRELATIONS BETWEEN THE MINERAL AND TRACE ELEMENTS OF ÇANAK CHEESE IN WINTER

\begin{tabular}{|c|c|c|c|c|c|c|c|}
\hline & $\mathrm{Cu}$ & $\mathrm{Fe}$ & $\mathrm{Zn}$ & $\mathrm{Mn}$ & $\mathrm{Mg}$ & $\mathrm{Ca}$ & $\mathrm{K}$ \\
\hline $\mathrm{Cu}$ & 1 & - & - & - & - & - & - \\
\hline $\mathrm{Fe}$ & 0.76 & 1 & - & - & - & - & - \\
\hline $\mathrm{Zn}$ & 0.335 & 0.114 & 1 & - & - & - & - \\
\hline $\mathrm{Mn}$ & 0.274 & $0.536^{*}$ & $0.534^{*}$ & 1 & - & - & - \\
\hline $\mathrm{Mg}$ & 0.210 & 0.377 & $0.749^{* *}$ & $0.627^{* *}$ & 1 & - & - \\
\hline $\mathrm{Ca}$ & 0.361 & 0.251 & $0.951^{* *}$ & $0.527^{*}$ & $0.806^{* *}$ & 1 & - \\
\hline $\mathrm{K}$ & $0.584^{* *}$ & 0.249 & $0.674^{* *}$ & $0.655^{* *}$ & $0.668^{* *}$ & $0.637^{* *}$ & 1 \\
\hline Ash & $0.467^{* *}$ & $0.702^{* *}$ & $0.626^{* *}$ & $0.510^{* *}$ & $0.743^{* *}$ & $0.757^{* *}$ & $0.560^{* *}$ \\
\hline
\end{tabular}

TABLE-3

CORRELATIONS BETWEEN THE MINERAL AND TRACE ELEMENTS OF ÇANAK CHEESE IN SUMMER

\begin{tabular}{|c|c|c|c|c|c|c|c|}
\hline & $\mathrm{Cu}$ & $\mathrm{Fe}$ & $\mathrm{Zn}$ & $\mathrm{Mn}$ & $\mathrm{Mg}$ & $\mathrm{Ca}$ & K \\
\hline $\mathrm{Cu}$ & 1 & - & - & - & - & - & - \\
\hline $\mathrm{Fe}$ & 0.127 & 1 & - & - & - & - & - \\
\hline $\mathrm{Zn}$ & 0.376 & $0.570^{* *}$ & 1 & - & - & - & - \\
\hline $\mathrm{Mn}$ & 0.106 & $0.690^{* *}$ & $0.608^{* *}$ & 1 & - & - & - \\
\hline $\mathrm{Mg}$ & 0.353 & $0.690^{* *}$ & $0.686^{* *}$ & $0.531^{*}$ & 1 & - & - \\
\hline $\mathrm{Ca}$ & 0.237 & 0.422 & $0.675^{* *}$ & $0.475^{*}$ & $0.547^{*}$ & 1 & - \\
\hline $\mathrm{K}$ & 0.143 & $0.500^{*}$ & $0.683^{* *}$ & $0.633^{* *}$ & $0.660^{* *}$ & $0.926^{* *}$ & 1 \\
\hline Ash & 0.312 & $0.605^{* *}$ & $0.704^{* *}$ & $0.501^{* *}$ & $0.605^{* *}$ & $0.652^{* *}$ & $0.696^{* *}$ \\
\hline
\end{tabular}

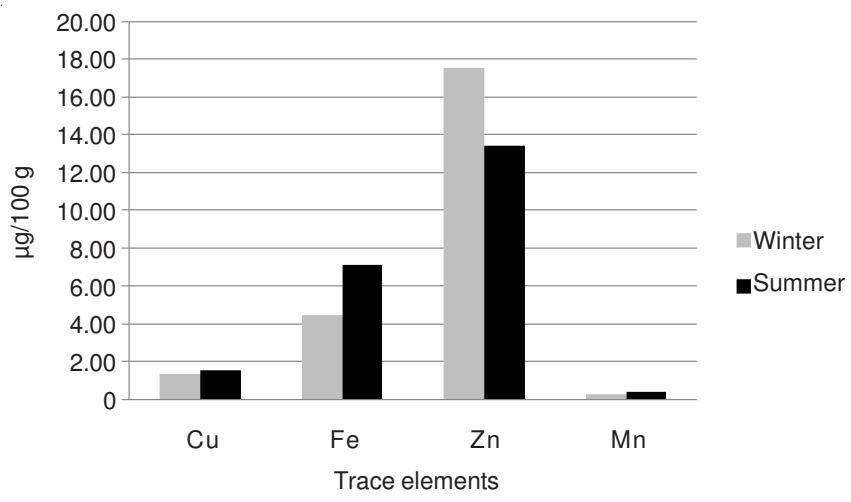

Fig. 2. Minor elements of Çanak cheese

soil through mineralization by crops, food processing or environmental contamination. The essential role of copper in maintaining health in both animals and humans has been known for many years ${ }^{22}$. The average daily dietary requirement of copper in the adult human has been estimated at $3 \mathrm{mg}^{23}$.

Copper is both in casein fraction and in the cationic form associated with enzymes and proteins or some molecular complexes with a weak bind ${ }^{24}$. Copper together with $\mathrm{Fe}$ is an index of the final quality of product, since these metals play a nutritional and biological function. However, they can present a problem in dairy technology because of their catalytic effect on the oxidation of liqids through the development of an unpleasant smell, preferably bounding proteins and membrane lipoproteins of milk fatty globule. The copper values in this study were found to be 1.32 in the winter and $1.55 \mu \mathrm{g} / \mathrm{g}$ in the summer, respectively. The mean value for the copper in this study was almost the same as that found in both White and Kasar cheese ${ }^{1,25}$, but higher than that of American cheese ${ }^{26}$, French cheese ${ }^{27}$ and White cheese ${ }^{11}$. Franco et al. ${ }^{28}$, suggested that the high content of $\mathrm{Cu}$ observed in the Babia-Laciana cheese is due to the contamination caused by the contact of the milk or the cheese with metallic utensils during manufacturing. There were no statistical differences regarding the $\mathrm{Fe}$ content during the cheesemaking season.

Copper is used in producing cheese-making equipment. Bearing in mind there are also high quantities of copper in agricultural medicine, passing from animal feed to milk, the availability of these levels of copper in cheese must be covered $^{25}$.

The consideration of the $\mathrm{Fe}$ and $\mathrm{Cu}$ contents of Çanak cheese found in this research entail more of a technological risk, rather than a nutritional risk as they may cause an elevated catalytic oxidation of cheese lipids ${ }^{1}$.

Manganese: Manganese is a normal component in living things, including both plants and animals, so manganese is also present in foods. For the majority of people, food is the main source of manganese. The Institute of Medicine recommends that the intake of manganese from food, water and dietary supplements should not exceed the tolerable daily upper limit of $11 \mathrm{mg} / \mathrm{day}^{29}$. In this research, manganese was determined as $0.23 \mu \mathrm{g} / 100 \mathrm{~g}$ in the winter and $0.39 \mu \mathrm{g} / 100 \mathrm{~g}$ in the summer. These results were in agreement with the findings of Kiliçel et al. ${ }^{30}$, Mendil ${ }^{8}$ and Tarakçi and Küçüköner ${ }^{31}$. The Mn found in this investigation was considerably lower than that in the literature ${ }^{32}$. The intake of Mn in our cheese samples was below the tolerable daily upper limit of the National Research Council.

Zinc: Zinc is a nutritionally essential metal and a deficiency results in severe health problems ${ }^{33}$. Zinc deficiency results in a wide spectrum of clinical effects depending on age, stage of development and the deficiencies of related metals. At the other extreme, excessive exposure to zinc is relatively uncommon and occurs only at very high levels. The zinc content of substances in contact with galvanized copper or plastic pipes may be increased. The maximum tolerable daily intake of zinc is $60 \mathrm{mg}^{23}$. 
The zinc values in this study were found to be 17.5241 $\mu \mathrm{g} / 100 \mathrm{~g}$ in winter and $13.41 \mu \mathrm{g} / 100 \mathrm{~g}$ in summer, respectively. The $\mathrm{Zn}$ content was the highest, followed by $\mathrm{Fe}, \mathrm{Cu}$ and $\mathrm{Mn}$. The mean value for the copper in this study was very similar to that found in Kashar cheese ${ }^{34}$ and Tulum and White cheese $^{25}$, but higher than that of Island White cheese ${ }^{26}$, Ordu Cerkez cheese and Kayseri Çömlek cheese ${ }^{8}$. These values are lower than the results reported by Kiliçel et al..$^{35}$ for Kes cheese and Van herby cheese, Kiliç et $a l .^{31}$ for Van herby lor cheese, herby cacik cheese. During the production process, using a different quality of metallic container affects trace metal levels in Çanak cheese. In addition, storage containers influence the metal levels ${ }^{15,36}$.

The correlation coefficient observed between $\mathrm{Zn}$ and $\mathrm{Mn}$ $(\mathrm{r}=0.564, p<0.05, \mathrm{r}=0.608, p<0.01)$ indicated that the cheese making season affects both in a similar way ${ }^{19}$.

The mean concentration of $\mathrm{Ca}$ and $\mathrm{Mg}$ in Çanak cheeses in the winter were higher $(p<0.01)$ compared to those in the summer. With respect to trace elements, the mean concentration of $\mathrm{Zn}$ was higher in the winter. Only $\mathrm{Fe}$ and $\mathrm{Cu}$ in Çanak cheese, respectively, presented some inverse behaviour with statistical $(p<0.01)$ significance. The tendency of higher mineral and trace element concentrations in summer could be due to a swifter dehydration of the cheeses, which is in agreement with other data from the literature ${ }^{20,37}$.

The seasonality (winter/summer) has a significant influence on the concentration of potassium, manganese, calcium and iron. The seasonal variation in the composition of milk, as is known, is due to changes in the bio-availability and quality of the pasteures throughout the year and to an increase in the proteolytic activity associated with the age of the lactation of the animal ${ }^{3}$.

\section{Conclusion}

The period within the cheese making season has a statistically significant effect upon the concentrations of $\mathrm{Ca}, \mathrm{Mg}$, $\mathrm{Fe}$ and $\mathrm{Mn}$. It appears that cheeses manufactured and ripened in summer are better mineral sources than those manufactured in the winter. The quantitative detection of trace and major elements is a good indicator of the quality of dairy products, which can be affected by several factors such as environmental pollution, peculiarities in processing techniques, hygienic conditions or dairy animal breeding and feeding specifics. The consumption of Çanak cheese may become widespread as mineral sources.

\section{REFERENCES}

1. N. Yuzbasi, E. Sezgin, Z. Yildirim and M. Yildirim, J. Food Qual., 32 73 (2009).

2. A. Lucas, D. Andueza, E. Rock and B. Martin, J. Agric. Food Chem., 56, 6801 (2008).

3. I.Gonzalez-Martin, J.M. Hernandez-Hierro, I. Revilla, A. VivarQuintena, I. Lobos-Ortega and C. Gonzalez-Perez, Czech. J. Food Sci., 27, 114 (2009).
4. A. Ayar, D. Sert and N. Akin, Environ. Monit. Assessm., 152, 1 (2009).

5. Anonymous, The Composition of Ewe's and Goat's Milk, International Dairy Federation Bulletin, 140, 5 (1981).

6. R.M. Feeley, P.E. Criner, E.W. Murphy and E.W. Toepher, J. Dairy Res., 61, 505 (1972).

7. A.G. Macedo and F.X. Malcata, J. Sci. Food Agric., 7, 409 (1997)

8. D. Mendil, Food Chem., 96, 532 (2006).

9. R. Moreno-Rojes, R. Pozo_Lora, G. Zurera-Cosona and M. AmonoLopez, Food Chem., 50, 373 (1994).

10. I. Gonzalez-Martin, J.M. Hernandez-Hierro, I. Revilla, A. Vivar-Quintena and I. Lobos-Ortega, Food Chem., 127, 147 (2011).

11. M. Merdivan, E. Yilmaz, C. Hamamci and R.S. Aygun, Food Chem., 87, 163 (2004)

12. S.S. Kirdar and Ö. Kursun, J Anim. Vet. Adv., 10, 2511 (2012).

13. IDF (International Dairy Federation), International Dairy Federation Bulletin (Brussels), No. 278 (1992)

14. N.R. Draper and H. Smith, Applied Regression Analysis, edn. 3, New York; Wiley (1998).

15. S.S. Kirdar, E. Ocak and S. Köse, Asian J. Chem., 25, 1643 (2013).

16. N. Yuzbasi, E. Sezgin, M. Yildirim and Z. Yildirim, Food Add. Cont., 20, 464 (2003).

17. S. Kiliç, C. Karagözlü, H. Uysal and N. Akbulut, Gida, 27, 229 (2002).

18. P.F. Fox, Developments in Dairy Chemistry-3 (Lactose and Minor Constituents), Nutritional Aspects of Minerals in Bovine and Human milks, USA, Ch. 7, p. 405 (1982).

19. A. Cichoscki, E. Valduga, A.T. Valduga, M.E. Tornadijo and J.M. Fresno, Food Control, 13, 329 (2002).

20. M.I.H. Garcia, P.P. Puerto, R.E.K. Barquera, J.C. Marton and C.R. Romeno, Int. Dairy J., 16, 182 (2006)

21. B. Prieto, I. Franco, J. Gonzalez, A. Bernardo and J. Carballo, Int. Dairy J., 10, 159 (2000).

22. D. Bakircioglu, Y.B. Kurtulus and G. Ucar, Food Chem. Toxicol., 49, 202 (2011)

23. FAO/WHO, Joint FAO/WHO Foods Standards Programme, Expert Committee on the Food Additives, Summary and Conclusions, In: 53rd Meeting, Rome, June 1-10 (1999).

24. O. Abollino, M. Aceto, M.C. Bruzzoniti, E. Mentasti and C. Sarzanini, Anal. Chim. Acta, 375, 299 (1998).

25. O. Yalçin and K.K. Tekinsen, Etlik Vet Mikro Derg, 21, 5 (2010).

26. J.A.T. Pennington, B.E. Young, D.B. Wilson, R.D. Johnson and J.E. Vanderveen, J. Am. Diet. Assoc., 86, 876 (1986).

27. M. Lamand, J.C. Tressol and J. Bellanger, J. Trace. Elem. Elect. Health Dis., 8, 195 (1994).

28. I. Franco, B. Prieto, A. Bernardo, J. Gonzalez Prieto and J. Carballo, Int. Dairy J., 13, 221 (2003).

29. National Research Council Recommended Dietary Allowances, National Academy Press, Washington, DC, edn. 10 (1989).

30. F. Kiliçel, Z. Tarakçi, H. Sancak and H. Durmaz, Y Yil Üni. Zir. Fak. Tar. Bil. Derg., 14, 41 (2004) (In Turkish).

31. Z. Tarakçi and E. Kuçukoner, Int. J. Food Sci. Technol., 43, 216 (2008).

32. Z. Tarakçi, H. Sancak, H. Durmaz and F. Kiliçel, Y Yil Üni. Sag. Bil. Derg., 8, 18 (2005) (In Turkish).

33. R.A. Goyer and T.W. Clarkson, In eds.: Klaasen and D. Curtis, Toxic Effects of Metals, Caserett and Doull's Toxicology: The Basic Science of Poisons, McGraw-Hill, New York, edn. 5 (1996).

34. O. Acar, Int. J. Food Safety, 13, 45 (2011).

35. F. Kilicel, Z. Tarakci, H. Sancak and H. Durmaz, Rev. Anal. Chem., 27, 101 (2008).

36. A. Vural, I. Narin, M.E. Erkan and M. Soylak, Environ. Monit. Assess., 139, 27 (2008)

37. A. Caridi, P. Micari, P. Caparra, A. Cufari and V. Sarullo, Int. Dairy J., 13, 191 (2003) 